\title{
FINDING GREENER PASTURES: THE LOCAL DEVELOPMENT OF AGRO- PASTORALISM IN THE ORDOS REGION, NORTH CHINA.
}

\author{
Tricia E. Owlett
}

\begin{abstract}
Department of East Asian Languages and Cultures, 521 Memorial Way, Stanford University, CA Stanford University, 94305-2145 Address correspondence to Tricia Owlett, E-mail: towlett@stanford.edu
\end{abstract}

\begin{abstract}
The results of recent archaeological research in the Ordos region provide new information on the timing and process of the development of agro-pastoralism in China. Integrating previously published archaeological materials with archaeological research conducted since 2000, this essay synthesizes our current understanding of archaeological data for the middle to late Neolithic period (ca. 3500-1800 $B C E)$ of the Ordos Region. The region is generally defined as including northern Shaanxi, southwestern Inner Mongolia, northeastern Ningxia, and western Shanxi Provinces. Research on the transition to large-scale reliance upon domesticated herd animals is just beginning, but zooarchaeological data indicate that caprine and cattle husbandry were important from the Late Neolithic period onwards. During this time, low-scale exploitation of wild resources obtained through hunting and foraging appear to have been complementary to the diet. Zooarchaeological reports on sites in the Ordos region provide a foundation for understanding the origins and development of agropastoralism in this part of Northwest China.
\end{abstract}

Keywords: The Ordos region; agro-pastoralism; human-environmental interaction; zooarchaeology.

\section{INTRODUCTION}

The archaeological record of the Ordos Region indicates that ceramic styles, stone tool traditions, and subsistence strategies changed from the middle Neolithic (ca. 5000$3000 \mathrm{BCE}$ ) to the late Neolithic period (ca. 3000-1800 BCE) (Han, J., 2003; Liu and Chen 2012: 228-232; Liu et al. 2014; Wang and Guo, 2016). For example, the middle Neolithic period is marked by the appearance of Yangshao period pottery that is very similar to the Banpo and Miaodigou types in the Central Plains and includes long narrow jars (ping), bowls (bo), and basins (pan) (Kang, 2013). Stone tool assemblages during this time include a wide variety of stone knives, microblades, grinding stones, adzes, axes, and spades (Liu et al., 2016). Conversely the late Neolithic is defined by the introduction of new grey and black paste ceramic traditions with several sub-regional stylistic variations that include tripods (li, yan, and ding), stemmed dishes (dou), and storage jars (guan) and lasts throughout most of the $3^{\text {th }}$ millennium and into the $2^{\text {nd }}$ millennium BCE (Sun, Z., 2005). Studies on stone tool assemblages during the late Neolithic period are still preliminary but also include a wide variety of stone knives, microblades, grinding stones, adzes, axes, and spades (Shaanxi, 2016).

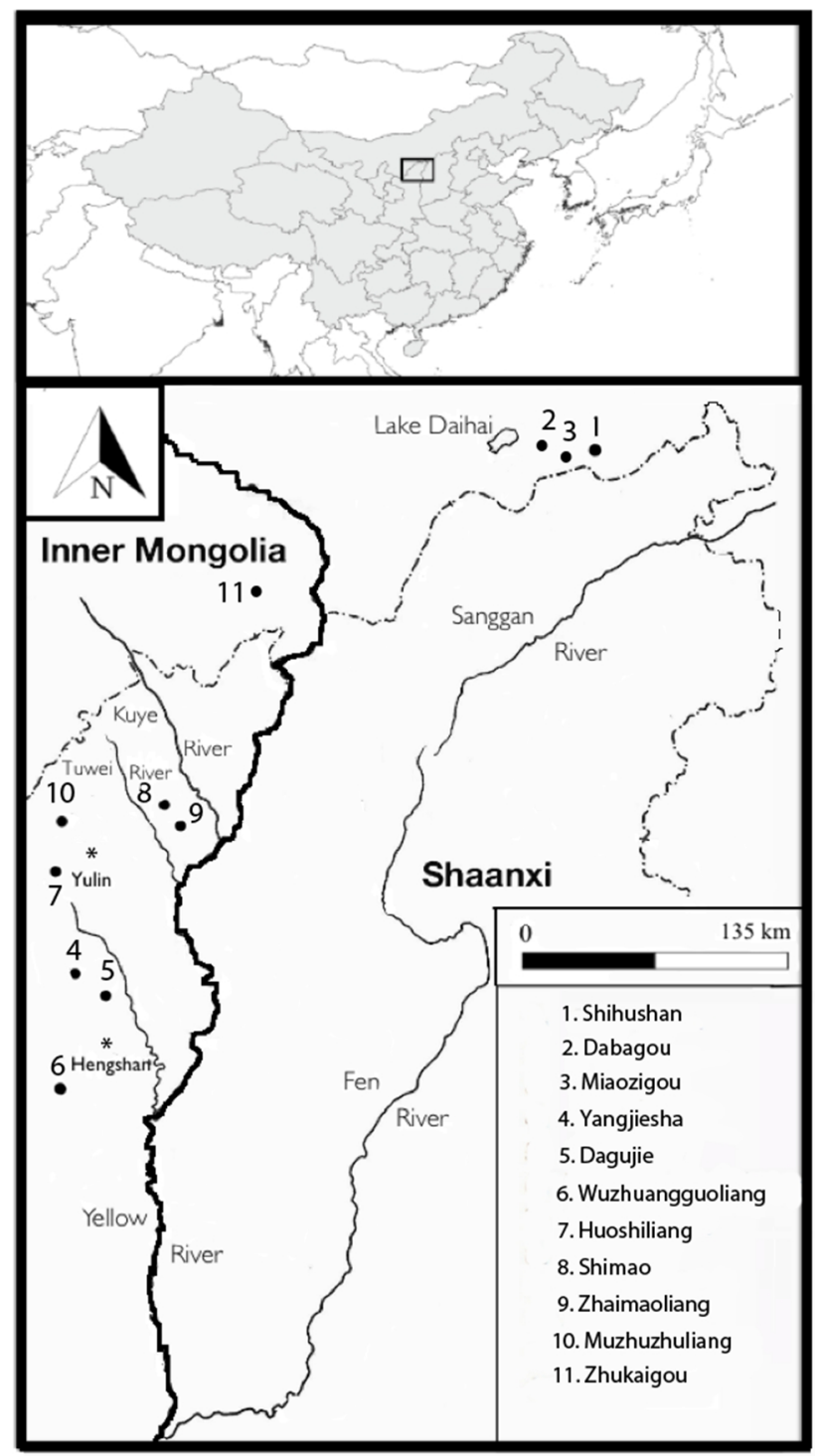

Figure 1. Location map showing the principle sites of the Ordos Region discussed in the text. Adapted from Wang and Zhang 2016. 
Table 1. Summary of key archaeological sites from the Ordos region, with zooarchaeological data discussed in the text.

\begin{tabular}{|c|c|c|c|}
\hline SITE NAME & TIME PERIOD (BCE) & $\begin{array}{l}\text { MAIN DOMESTIC } \\
\text { ANIMAL TAXA } \\
\text { (MNI) }\end{array}$ & SOURCES \\
\hline 1. Shihushan & c. $3500-3400 \mathrm{BCE}$ & Pig (15) & $\begin{array}{l}\text { Huang et al. 2001; Flad et al. 2007; Liu et al. 2014; Liu and Chen 2012: 228- } \\
\text { 229; Dodson et al. } 2014 .\end{array}$ \\
\hline 2. Dabagou & c. $3800-3000 \mathrm{BCE}$ & Pig (5), Cattle (2) & Inner Mongolia 2003; Flad et al. 2007 \\
\hline 3. Miaozigou & c. $3800-3000 \mathrm{BCE}$ & Pig (5), Cattle (2) & Inner Mongolia 2003; Flad et al. 2007; Liu and Chen 2012: 228-229 \\
\hline 4. Yangjiesha & c. $3020-2890 \mathrm{BCE}$ & Pig (15), Sheep (1) & Hu et al. 2013 \\
\hline 5. Dagujie & Late Yangshao Period & Pig (1), Sheep (1) & Hu et al. 2012 \\
\hline $\begin{array}{l}6 . \\
\text { Wuzhuangguoli- } \\
\text { ang }\end{array}$ & Late Yangshao Period & Pig (45) & Hu et al. 2005 \\
\hline 7. Huoshiliang & C. $2150-1900 \mathrm{BCE}$ & $\begin{array}{l}\text { Pig (13), Caprinae (61), } \\
\text { Cattle (9) }\end{array}$ & Hu et al.2008; Liu and Chen 2012:228-229; Dodson et al. 2014 \\
\hline 8. Shimao & c. $2300-1800$ BCE & $\begin{array}{l}\text { Pig (17), Caprinae (52), } \\
\text { Cattle (11) }\end{array}$ & Owlett et al. in press; Hu et al. 2016; Zhao 2016 \\
\hline 9. Zhaimaoliang & Late Neolithic Period & $\begin{array}{l}\text { Pig (6), Caprinae (10), } \\
\text { Cattle }(6)\end{array}$ & Owlett et al. in press; \\
\hline $\begin{array}{l}\text { 10. Muzhu- } \\
\text { zhuliang }\end{array}$ & $\begin{array}{l}\text { Late Neolithic to } \\
\text { Erlitou Period }\end{array}$ & $\begin{array}{l}\text { Pig (11), Caprinae (55), } \\
\text { Cattle (20) }\end{array}$ & Wang and Guo 2016 \\
\hline 11. Zhukaigou I- & c. $3000-1900$ BCE & $\begin{array}{l}\text { Pig (27),, Sheep (32), Cat- } \\
\text { tle (14) }\end{array}$ & Huang et al. 1996; Flad et al. 2007; Liu and Chen 2012: 228-229 \\
\hline
\end{tabular}

Regional settlement surveys do not currently allow us to have a detailed examination of differences in settlement patterns and regional settlement hierarchies between the middle Neolithic Yangshao and later periods (Indrisano, G., 2006; Inner Mongolia and Japan, 2001; Sun, Z. 2016; Tian and Guo, 2004). However, it is apparent that a number of larger sized settlements begin to emerge during the late Neolithic period. Similarly, excavations of single sites in this region demonstrate that many large and small late $\mathrm{Ne}-$ olithic period settlements emerge with fortified walled features primarily constructed of locally available sandstone and earth (Guo and Sun, 2016).

Despite a rich and emerging archaeological tradition in the region, questions remain regarding the management and use of domesticated animals and the role animal husbandry played in social change during this transition. This paper reviews the earliest evidence for agro-pastoralism in the region and discusses how animal husbandry changed over time at a series of sites ranging from $3500 \mathrm{BCE}$ to 1800 BCE (Fig. 1). It synthesizes previous research on the study of early agro-pastoralism in the Ordos Region, which until now has largely been published only in Chinese journals and is not readily accessible to non-Chinese speakers.

The archaeology of early pastoralism in China has long been a part of East Asian archaeology, and while much progress has been made to understand this phenomenon in prehistory many of these studies neglect to include long-term investigations of zooarchaeological remains (Barfield, 1989; Di Cosmo, 2002; Fuller et al., 2011; Linduff, 1997; Rhode et al., 2007; Shelach, 2005). Recent studies of early pastoralism in China have contributed to the study of pastoralism globally by investigating human adaptations to climatic change (D’Alpoim Guedes et al., 2014; D’Alpoim Guedes, 2015), as well as to the understanding the sociopolitical organization of early pastoral societies in Eurasia (Wagner et al., 2011). At the same time, the recovery of animal remains in China is increasingly becoming a systematic and problem-oriented discipline and more recent interdisciplinary studies of zooarchaeology have begun investigating issues such as salt production, bone tool production systems, and urban foodways (e.g. Campbell et al., 2011; Flad, 2005; Brunson et al., 2015). However, few studies of animal remains in this region have linked these data to pastoralism or agro-pastoralism. Scholars have published some tentative work related to agro-pastoralism in the Ordos Region (Liu and Chen, 2012: 228-229; Shelach, 2009b; Wang, 1994), but until recently the faunal evidence was too sparse to effectively trace long-term regional developments in the agro-pastoral economy. Within the last twenty years the economy of the Ordos region has experienced growth due to interest in natural gas and coal production, and many construction projects have exposed archaeological habitation sites that are largely excavated on a salvage archaeology basis. This recent economic activity has produced a growing body of zooarchaeological evidence from middle and late Neolithic sites that allows us to begin to investigate long-term regional transition to agropastoralism in the Ordos Region.

The following discussion is a synthesis of the most recent archaeological data on the Ordos Region, with particular attention to subsistence, environment, and increasingly complex agro-pastoral systems. The Ordos Region can be separated into four main cultural and geographic zones: (1) western Shanxi, (2) northeastern Ningxia, (3) northern Shaanxi Province, and (4) southwestern Inner Mongolia. This paper reviews the new data generated from zooarchaeological analysis found at six middle Neolithic period sites and at five late Neolithic sites from southwestern Inner Mongolia and northern Shaanxi provinces. These studies help us reconstruct early agro-pastoralism in North China and bring the data to the worldwide discussion in English. The sites with evidence of agro-pastoral animal husbandry discussed in this paper are listed in Figure 1 and Table 1. 


\section{DEFINING AGRO-PASTORALISM AND HUMAN- ANIMAL RELATIONSHIPS}

There have been many attempts to define the term pastoralism. It is commonly defined as being both an economic adaptation (Khazanov, 1984; Krader, 1959) and a cultural phenomenon (Ingold, 1980). Pastoralists are people who largely rely upon the production and consumption of domestic herd animals for material resources such as meat, dairy, fiber, and dung, along with art and symbolism, wealth, labor, and protection (Arbuckle, 2012; Miller and Marston, 2012; Orton, 2010). Cross-culturally the characterization of pastoral economics in the archaeological record is recognized as being particularly difficult, and archaeologists have used architectural, spatial, archaeobotanical, and zooarchaeological evidence to understand this phenomenon worldwide (e.g. Capriles and Tripcevich, 2016; Chang and Koster, 1986; Frachetti, 2012; Hammer, 2014; Honeychurch and Makarewicz, 2016; McClure, 2015; Spengler, et al. 2013b).

Pastoralists rarely rely entirely on resources derived from animals as economic staples and often supplement their diet with multiple resources including foraging, hunting, fishing, exchanging food, and cultivating plant crops (Salzman, 1971). Agro-pastoralism is in its simplest form a type of multi-resource pastoralism in which some communities live within sedentary agricultural villages or are fully nomadic but heavily rely upon domesticated herd animals as a fundamental part of their subsistence strategies and way of life (Cribb, 1991; Lane, 2006). In agro-pastoralist communities there are often constant interconnected shifts between the dynamics of herding and farming through time (Miller et al., 2009). These changes are often related to the larger locally situated socio-political, ecological and geographical landscapes in which these communities exist (Frachetti, 2012). Similarly, agro-pastoral societies may vary widely in their annual and seasonal mobility patterns depending upon ecological factors such as water and pasture availability in addition to herd composition and demographics (Spengler, 2013a).

The cattle, sheep, and goats raised by the early agropastoral communities of the Ordos Region were domesticated in south-west Asia and brought to China via multiple routes, possibly through the Hexi Corridor (Flad et al., 2007), or through the Gobi Desert in southern Mongolia (Liu and Chen, 2012; Janz, 2016) (Fig. 1.). To date, very little zooarchaeological work has been carried out in contemporary sites in the Gobi Desert, the Mongolian highlands, or the Altai region, although recent work in the upper Paleolithic and early Neolithic has greatly supplemented our understanding of the early periods of these regions (Holguín and Sternberg, in press; Janz, 2016; Janz et al., 2009). Further research in these areas is needed to determine the routes used to introduce early herd animals into the Ordos Region.

\section{THE BEGINNING OF SMALL-SCALE ANIMAL HUSBANDRY AND THE YANGSHAO PERIOD}

The economy of the Yangshao Period in the Ordos Region is roughly similar to that of the Yangshao period in the
Central Plains. The Yangshao culture dates from approximately 5000-3000 BCE and is commonly divided into an early (ca. 5000-4000 BCE), middle (ca. 4000-3500 BCE), and late period (ca. 3500-3000 BCE). During this time people lived in sedentary settlements and produced handcoiled ceramics that were decorated or painted with pigments. Both ground and chipped stone tools were utilized and individuals practiced mostly hunting, rearing of domesticated livestock, gathering, and agriculture through a lesser degree of millet cultivation (Setaria italica and Panicum milliaceum) (Kang, 2013; Liu et al., 2016). Animal bones of six Yangshao period sites in this region have been subjected to zooarchaeological analysis. These include three archaeological sites in southwestern Inner Mongolia (Shihushan, Miaozigou, Dabagou) (Huang, 2001; Inner Mongolia, 2003) and three archaeological sites in northern Shaanxi Province (Yangjiesha, Wuzhangguoliang, Dagujie) (Hu et al., 2005, 2012, 2013).

The beginning of small-scale animal husbandry in this region (sheep, goats, pigs, and cattle) is poorly understood, although it is very clear that by approximately the early Yangshao period (ca. 5000-4000 BCE) sheep and pig husbandry was being exploited on a very small scale, with an intensive utilization of both large and small game. For example, analysis of faunal remains from Shihushan has demonstrated that domesticated pigs only account for approximately $11 \%$ of the faunal remains $(\mathrm{MNI}=15)$ (Fig 2) (Daihai Region Investigation Team, 2001; Huang, 2001; Liu et al., 2014; Flad et al., 2007). Some of the first concrete zooarchaeological evidence of possible small-scale animal husbandry comes from Shihushan where direct radiocarbon dating upon three possibly domesticated sheep samples (Ovis sp.) has confirmed a date of 4700-4400 BCE (Dodson et al., 2014). These sheep bones were found in association with other domestic species such as pigs and dogs and were therefore suggested to also be domesticated. However, ancient mtDNA was not successfully obtained from these samples, and more work is needed to confirm the domestication status of these sheep.

Furthermore, it is possible that these sheep remains could represent one of the many wild bovids in the region. The appearance of sheep bones within the assemblage might represent a stage of pre-domestication herding strategies, or these finds might be representative of wild sheep that were initially hunted by forager-gatherers (Flad et al. 2007; Brunson, 2015). There are many different breeds of native wild bovids in Northwest China including argali mountain sheep (Ovis ammon), blue sheep (Pseudois nayaur), domestic goat (Capra hircus), domestic sheep (Ovis aries), Himalayan goral (Nemorhaedus goral), and the Chinese serow (Capricornis serow) along with several species of Gazella and Procapra. Challenges in osteometrics and osteomorphology currently exist in accurately distinguishing between morphologically similar bones of these various wild and domestic species (Wang, Y., 2015).

Analyses of zooarchaeological remains from two late Yangshao period sites of Miaozigou and Dabagou in southwestern Inner Mongolia have similarly demonstrated that small scale cattle husbandry had possibly spread from nort- 


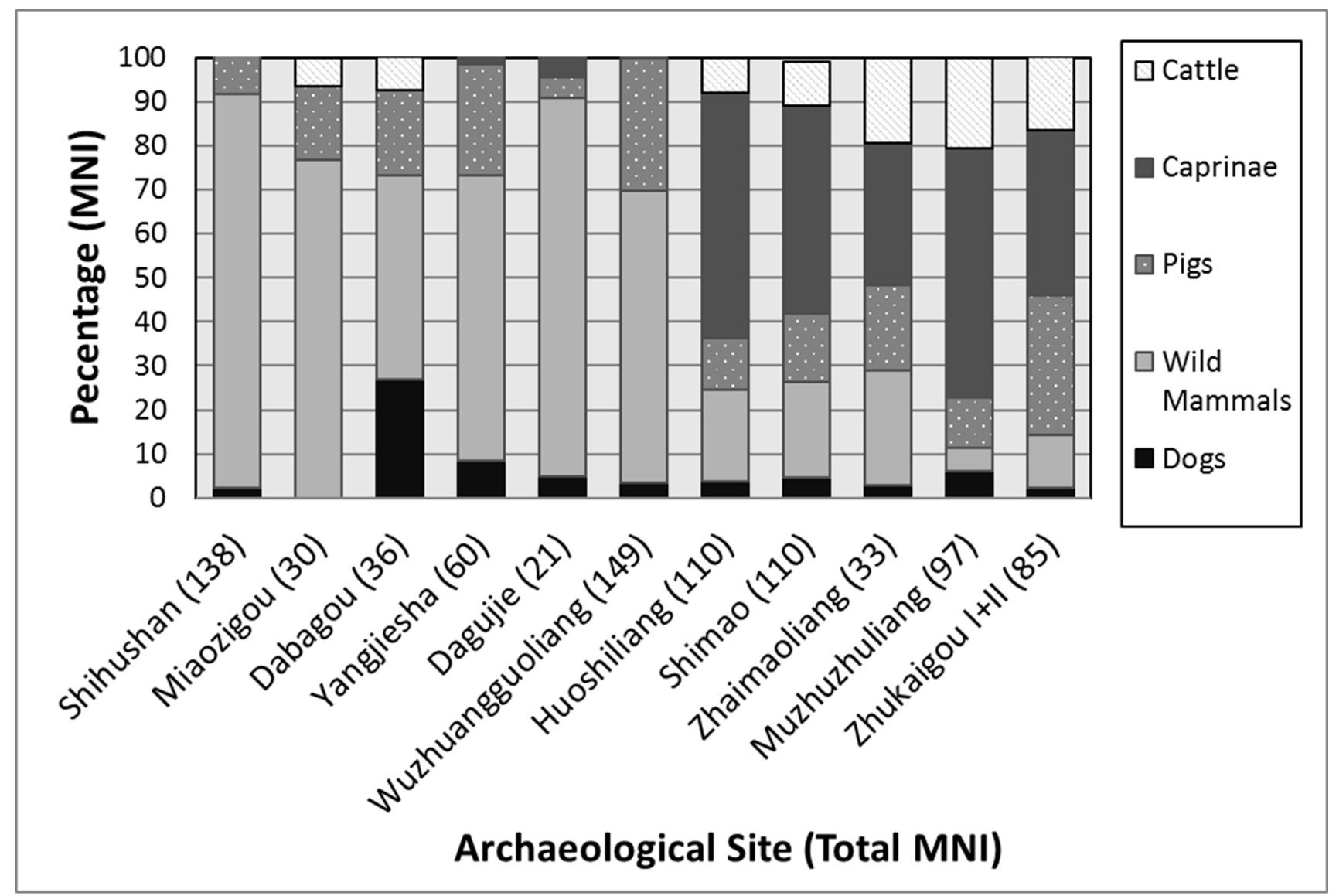

Figure 2. The increasing incidence of herd animal exploitation through time from six middle Neolithic Yangshao period sites and five late Neolithic sites in the Ordos Region. Percentages are based upon MNI values, as they were comparable from the sites. Total MNI values are listed in parentheses.

hwestern China into southwestern Inner Mongolia as early as 3500 BCE (Table 1). Challenges exist in accurately distinguishing between morphologically similar bones of native wild bovines such as wild aurochs and wild water buffalo. Like Shihushan, pigs are secondary in importance and often make up approximately $15 \%$ of the animals exploited at these two sites. Deer (red deer and roe deer) and other large game such as Mongolian gazelle were the primary animals consumed at these three sites in southwestern Inner Mongolia.

Analyses of zooarchaeological remains from two late Yangshao period sites of Dagujie (3500-3000 BCE) and Yangjiesha (3020 BCE-2890 BCE) in Hengshan County, northern Shaanxi province have demonstrated that small scale sheep herding had possibly spread from northwestern China into northern Shaanxi Province as early as 3000 BCE (Table 1) (Hu et al., 2012, 2013). One sheep was identified at both Yangjiesha $(\mathrm{MNI}=1)$ and Dagujie $(\mathrm{MNI}=1)$, and it is unclear whether or not these sheep were wild or domesticated. Pigs are secondary in importance at these two sites and often make up approximately less than $15 \%$ of the animals exploited. Among the identified pigs, $44 \%$ of the specimens were 4-6 months of age $(\mathrm{MNI}=4)$, and
$22 \%$ of the pigs were culled between 18-24 months $(\mathrm{MNI}=2)$. Kill off patterns are commonly utilized to understand domestication and intentional culling practices. However, such small MNI values currently present within these assemblages limit the construction of statistically reliable mortality profiles.

Small game is more heavily exploited in northern Shaanxi Province during this time. Hare were the primary animal consumed at many of these sites often comprising approximately $40 \%$ of the faunal remains. For example, at the late Yangshao period (3500-3000 BCE) site of Wuzhuangguoliang, Jingbian County (Hu et al., 2005) (Fig 2 ), hares were the primary animal consumed, making up over $46 \%(\mathrm{MNI}=69)$ of the faunal remains. Hare are fastmoving small prey whose capture often requires significant energetic cost (Stiner et al., 2000). They are generally solitary animals throughout much of the year, and it is possible that hunters may have encountered hares individually rather than in mass numbers while they travelled across the landscape (Hockett, 2002). In addition to a source of meat and marrow, hare fur was likely vital to some foragers to produce raw materials, winter clothing, and insulation (Yi et al., 2013; Speth and Spielmann, 1983). 


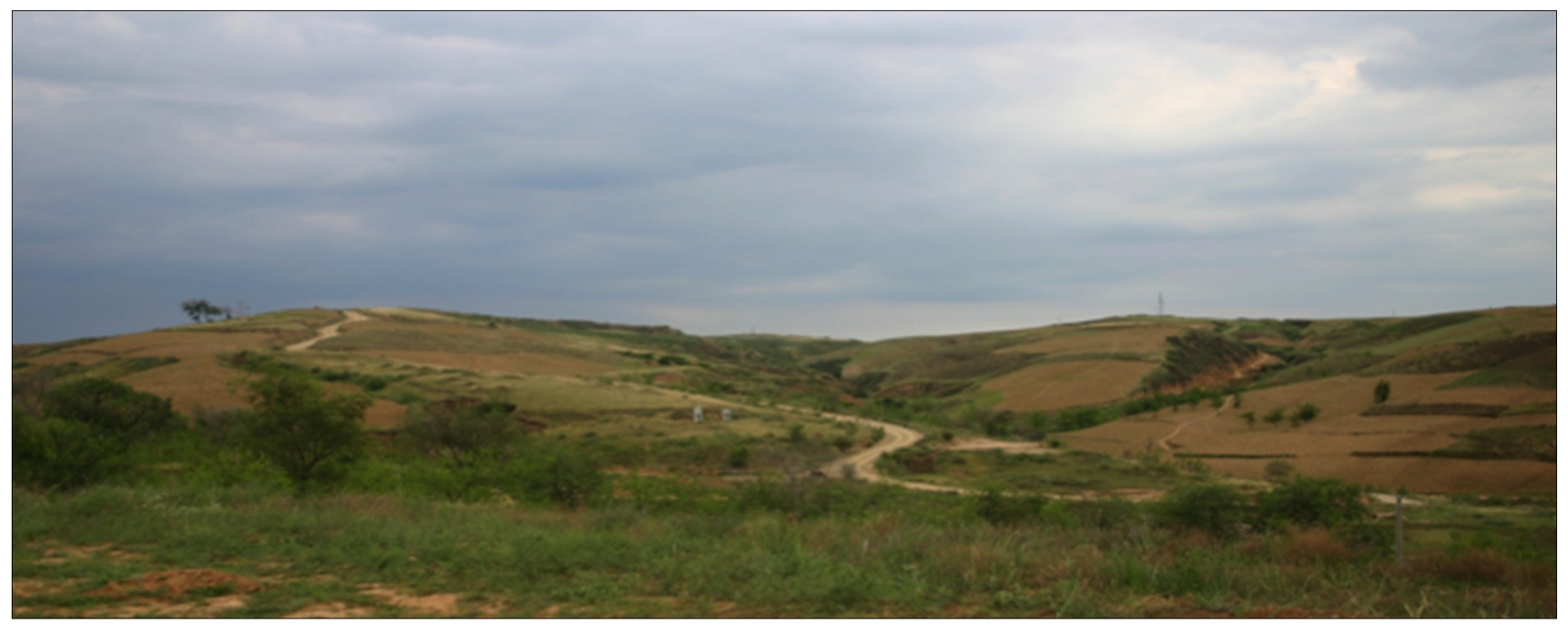

Figure 3. Landscape near Shimao in Shenmu County, northern Shaanxi. (Photo by the author.)

In addition to small game, pigs are secondary to the diet and comprised over $30 \%(\mathrm{MNI}=69)$ of the faunal remains at Wuzhuangguoliang. Among the identified pigs, 61\% $(\mathrm{MNI}=17)$ of the specimens were 4-9 months of age, and $18 \%(\mathrm{MNI}=5)$ of the pigs were culled between $18-24$ months. Stable carbon and nitrogen isotope analysis of bone collagen from wild and domesticated animals at Wuzhuangguoliang suggests that the pigs, dogs, and rodents consumed a diet supplemented by $\mathrm{C} 4$ plants, implying that pigs were likely being foddered or were consuming human scraps or waste (Guan et al., 2008).

\section{SUMMARY}

These data indicate that there was a diverse base of animals both hunted and herded during the Yangshao period, and that production and consumption were largely oriented toward locally available wild resources. Only small-scale exploitation of domesticated herd animals began in the Ordos Region at this time. In sites located in southwestern Inner Mongolia (Shihushan, Dabagou, Miaozigou) the earliest economy was largely based on hunting and foraging large wild game animals such as deer, and domesticated animals and small game were supplementary to the diet. In sites located in northern Shaanxi province (Yangjiesha, Wuzhuangguoliang, Dagujie) the earliest economy was more heavily dependent upon a pig-based economic system and the consumption of small game such as hare. Deer did not play as significant a part of the diet in northern Shaanxi province.

Rainfall and vegetation differences between southwestern Inner Mongolia and northern Shaanxi Province might be reflected in the exploitation of different proportions of local wild animals during this time. Today, southwestern Inner Mongolia is located in a transitional area between semi-humid and semi-arid climates and the vegetation is largely temperate steppe with deciduous forests. Mean annual precipitation is $423 \mathrm{~mm}$ per year (Xu et al., 2005). Red deer are generally regarded as selective grazers that feed upon herbaceous and woody plants in mixed forests and grasslands and would have thrived in this environment (Chen et al. 1998). Alternatively, northern Shaanxi has a generally semi-arid climate and mean annual precipitation ranges from 150-450 $\mathrm{mm}$ (Wu and $\mathrm{Ci}, 2002)$. Hare (Lepus capensis) have a higher tolerance for aridity and can adapt their diet to browse upon shrubs and short grasses (Kerley, 1990), which typify much of the landscape in northern Shaanxi province today (Figure 3). This ability to adapt to habitats with lower precipitation and thinner soils may explain why Lepus was plentiful in northern Shaanxi Province faunal assemblages during the Yangshao period.

The presence of sheep bones from the Shihushan site constitutes the earliest possible evidence for herd animals in southwestern Inner Mongolia. Conversely the presence of sheep from the late Yangshao period sites of Yangjiesha and Wuzhuangguoliang constitutes the earliest evidence for herd animals in northern Shaanxi Province. It is possible that sheep herding spread into southwestern Inner Mongolia and northern Shaanxi province at different rates or pathways. Sheep are believed to have been domesticated in the Near East by approximately $8500 \mathrm{BCE}$ and the progenitor of the domesticated sheep is the Asiatic mouflon (Ovis orientalis) (Bruford and Townsend, 2006; Zeder, 2011). Recent studies of ancient mitochondrial DNA of domestic sheep from four Bronze Age sites in China indicate that among the three different mtDNA lineages across Eurasia (lineages A-C), lineage A has the highest frequency within East Asia (Cai et al., 2007, 2011). These findings appear consonant with current archaeological evidence for early domestication and diffusion of sheep from Eurasia into China. By the late $3^{\text {rd }}$ millennium BCE, domestic varieties of sheep/goats comprise staple foods for small groups of early Bronze Age mobile pastoralists in the eastern central Eurasian steppe region (Anthony, 2007; Frachetti \& Benecke, 2009). Other than Shihushan, recent studies at three sites located in the Hexi Corridor (Dahezhuang, Qinweijia, 
and Donghuishan) similarly show important evidence for sheep domestication (Flad et al., 2007).

Cattle appear to be the next earliest herd animals utilized in the Ordos Region, however they were not present in this region until the late Yangshao period (ca. 3500-3000 $\mathrm{BCE}$ ). The presence of either wild or domesticated cattle bones from the Dabagou and Miaozigou sites constitutes the earliest evidence for bovine herd animals in southwestern Inner Mongolia. It is possible that this might represent a stage of pre-domestication herding strategies or these finds might be representative of wild cattle hunted by forager-gatherers. Inhabitants of this region might have experimented with managing populations of indigenous wild aurochs in north China long before the introduction of cattle during the middle Neolithic period (Brunson, 2016). However, the proportion of cattle remains in the overall faunal assemblages at these two sites remains fairly low, representing less than $5 \%$ of identified specimens. Zooarchaeological evidence indicates that domestic taurine cattle (Bos taurus) were first domesticated from wild auroch (Bos primogenius) stocks in the Near East and South Asia (Bradley et al., 1998; Bradley and Magee, 2006; Cai, 2007). In general, the use of domesticated cattle in China is thought to have begun between 2500-2000 BCE. Among the five most common mtDNA haplogroups of Bos taurus, haplogroups T1, T2, and T3 are most common in the Near East, Africa, and Europe, and haplogroup T4 is found only in East Asia. The earliest known domesticated cattle remains have been identified from the Qijia culture sites of Qinweijia and Dahezhuang in Gansu province (Lu, 2010; Flad et al., 2007; Yu et al., 2011).

Finally, middle Neolithic Yangshao period sites in the Central Plains are largely characterized by heavy reliance on domestic pigs (Luo, 2012). However, it appears that in the Ordos region, pig husbandry was a relatively minor component of the diet during this time. Based on the limited ageing data available from Wuzhuangguoliang and Dagujie, management of said stock during this period involved culling of juvenile pigs between ages of 4-9 months, and culling of adult pigs between the ages of 18-24 months (Hu et al., 2005, 2012).

\section{EARLY AGRO-PASTORALISM AND THE LATE NEOLITHIC PERIOD}

Animal bones recovered from excavated sites suggest that most middle Neolithic period Yangshao communities relied heavily upon hunting large and small game and, to a lesser extent, on pig husbandry. However, gradual changes in economic and social organization are evident after 2500 $\mathrm{BCE}$ in the Ordos region. There are no zooarchaeological assemblages that span from the Late Yangshao to the beginning of the late Neolithic (3000-2500 BCE), therefore it is difficult to understand this transition from any one site. Agro-pastoralism probably existed at a low level for many years as part of diversified household strategies, well before it became an element of a larger subsistence economy. This transformation was likely a gradual process, commencing in the preceding Yangshao period and continuing past the end of the late Neolithic. Eventually, small-scale innovations in animal husbandry became part of a much larger subsistence-based transformation brought on by and related to more significant societal and economic changes. Domestic plant and animal technologies became primary features of late Neolithic subsistence systems, providing households and communities with a steady source of food products throughout the year.

Zooarchaeological studies and meta-analyses hold promise in understanding early agro-pastoralism in China, but they are also currently fraught with a few methodological problems. Although wild taxa have been recovered at several middle to late Neolithic sites, there is a low reported MNI of such fauna. The absence of small mammals, reptiles, birds, and fish may be symptomatic of a lack of flotation and the use of coarse screens, which favor the recovery of larger animals (Casteel, 1972; Payne, 1975; Quitmyer, 2004). Nevertheless, it is clear that there was a selective base of animals herded during the late Neolithic period, and that production and consumption were largely oriented towards these taxa.

Secondly, in the Ordos Region different criteria have been utilized to identify sheep (Ovis sp.), goats (Capra sp.), and caprines (sheep/goat). Domesticated sheep (Ovis aries) and goats (Capra hircus) have extraordinarily similar dental and skeletal anatomies, and much research has attempted to discover and refine the few morphological and metric criteria that allow them to be reliably distinguished worldwide (e.g. Balasse and Ambrose, 2005; Boessneck, 1969; Zeder and Pilaar, 2009). Therefore, zooarchaeologists working in China must also work collaboratively to standardize and integrate these identification procedures for the identification of sheep, goat, and sheep/goat more thoroughly in the future. Previous summaries of domesticated goat management and exploitation in China have identified the Erlitou site Phase IV (1750 BCE) as the first location with the substantial evidence of domestication (Yuan, J. 2010). However, it is possible that goats arrived in China much earlier, but more work is needed to specifically address the identification and domestic status of these possible goat samples.

However, there is considerable preliminary evidence for a significant reliance on domesticated herd animals at several sites in this region (Owlett et al., in press; Hu et al., 2008; Wang and Guo, 2016; Huang, 2001). Faunal assemblages from late Neolithic period sites show that ovicaprids were the most common domesticated species during this period, while the numbers of cattle and domesticated pigs also increased in importance.

In the following section I will review faunal data from five sites in northern Shaanxi Province- Shimao, Zhaimaoliang, Huoshiliang, Muzhuzhuliang, and one site in southwestern Inner Mongolia- Zhukaigou Phases I-II- provide a window into the nature of early agro-pastoral systems in the Ordos Region as well as their evolution from the middle to the later Neolithic and beyond (Owlett et al., in press: Hu et al., 2008; Wang and Guo, 2016; Huang, 2001). Results indicate that specialized cattle, sheep and goat herding was dominant in the subsistence economy while little hunting was practiced. Although detailed information on this 
segment of the Ordos Region prehistory is not abundant, available data reveal a succession of cultural transformations within the Neolithic period. These transformations seem to have been fostered by both environmental and social change, and possibly by population movement.

The site of Huoshiliang (ca. 2150-1900 BCE) in northern Shaanxi Province is the earliest known Late Neolithic site in the Ordos Region that has yielded evidence of how and when early agropastoralism was brought to this region (Fig. 1; Table 1). Eighty-three percent of the assemblage represents the remains of domestic taxa. Only 21 specimens attributable to wild taxa were identified. The large quantity of goat remains at the site $(\mathrm{MNI}=46)$ far surpasses that of sheep. The presence of goat bones from this site constitutes the earliest evidence for goats in this entire region (Hu et al., 2008; Liu and Chen, 2012: 228-229). Stable carbon isotope analysis $\left(\delta^{13} \mathrm{C}\right)$ on sheep from the Huoshiliang site suggests that millet formed a large proportion of the diet and was possibly being provided as fodder by inhabitants (Dodson et al., 2014).

Shimao is a 400 hectare walled site, located in Shenmu County in Northern Shaanxi Province The site dates from 2350-1800 BCE and consists of a stone-walled settlement, dense residential areas, craft workshops and cemeteries (Shaanxi et al., 2013). Faunal analysis of these remains identified at least 15 species, including alligator, pheasant, sewer rat, chinese zokor, gansu zokor, rabbit, dog, horse, domesticated pig, goat, sheep, and cattle (Hu et al., 2016; Owlett et al., in press). Domesticated animals were the primary animal consumed at the site and composed over $95 \%$ (MNI) of the faunal remains. Wild animals make up a small proportion of the diet and composed approximately 5\% of the MNI. The ${ }^{87} \mathrm{Sr} /{ }^{86} \mathrm{Sr}$ results from late Neolithic animal teeth from this site show that there is no significant variability in values. These isotope data suggest that animal husbandry during the Late Neolithic was rather localized, and that pigs, sheep, and cattle often lived their whole lives close to the place where they were raised (Zhao et al., 2016).

Zhaimaoliang is located $20 \mathrm{~km}$ south of Shimao on the Kaiguangchuan River, a branch of the Tuwei River. The site was discovered in 1988 and excavated between 2014 and 2015 by the Shaanxi Provincial Institute of Archaeology. Faunal analysis identified 12 species $(\mathrm{MNI}=33)$, including racoon dog, pheasant, brown rat, gazelle, hare, freshwater shellfish, domesticated dog, pig, goat, sheep, and cattle (Owlett et al., in press; Sun, 2016). Domesticated animals were the primary animal consumed at the site and composed over $69 \%(\mathrm{MNI}=23)$ of the faunal remains. Wild animals made up a smaller proportion of the diet and composed approximately $30 \%$ of the remains $(\mathrm{MNI}=10)$.

At the site of Muzhuzhuliang excavators discovered an enclosed moat, 52 house foundations, 222 ash pits, as well as eight burials and ceramics kilns dated to the Late Neolithic period (Sun, 2016). Faunal specimens reported from the site represent a minimum of 97 individuals. Domestic herd animals such as cattle, sheep and goat make up $77 \%$ of the MNI, pigs compose $11 \%(\mathrm{MNI}=11)$, and wild animals only constitute approximately $5 \%$ of the MNI (Wang and Guo, 2016). Although the faunal remains from this site indicate an overwhelmingly pastoral food economy, the stable nitrogen isotope results from seven human remains $\left(\delta^{15} \mathrm{~N}=7.8-9.5\right)$ indicate these individuals consumed a diet only moderately reliant on animal protein (Chen et al., 2015).

Finally, excavations at Phase I and II at the Zhukaigou site in southwestern Inner Mongolia (3000-1900 BCE) have revealed a similar large-scale reliance upon pig $(\mathrm{MNI}=27)$, sheep $(\mathrm{MNI}=32)$, and cattle $(\mathrm{MNI}=14)$ during the Late Neolithic period (Liu and Chen, 2012: 228-229). These three taxa remain dominant species of the site throughout the occupation, however pig becomes the most abundant during Phase II (Huang et al. 1996).

The discussion of animal husbandry must also consider plant cultivation, as the two were most likely practiced together in a small-scale but intensive system close to settlements. Detailed multi-site archaeobotanical studies are lacking for many of the middle to late Neolithic sites in the region. However, the current knowledge of plant utilization in this region will be summarized below. Residue remains and usewear patterns on sandstone grinding stone tools unearthed from the Shihushan I and Shihushan II sites, dating to the mid- $5^{\text {th }}$ millennium BCE have shown that early Yangshao Period inhabitants in the Daihai possibly managed a wide range of plants, including various underground storage organs (USO) such as tubers, roots, rhizomes, and bulbs (Liu et al., 2014). In addition to foraging for nuts, and wild grasses, inhabitants engaged in a limited level of millet production. Phytolith analysis from the late Yangshao to late Neolithic period site of Wangmushan demonstrates that different species of millet became the staple food crops cultivated during the late Yangshao Period. Broomcorn millet ( $P$. miliaceum) was the most numerous species identified followed by foxtail millet ( $S$. italica) (Xia et al., 2015). Seeds from three late Neolithic sites from this region demonstrate that subsistence was based on intensive agriculture focused upon both broomcorn and foxtail millet. At the sites of Muzhuzhuliang, Shengedaling (Wang and Guo, 2016), along with Zhaimaoliang (Gao et al., 2016), millet often composes more than $50 \%$ of the floatation remains. Other important wild plants included Chenopodium album, Leguminosae sp., or wild grasses which are commonly found in lesser amounts in archaeobotanical assemblages during this time period (Gao et al., 2016). Along with remaining millet husks and stalks, these plants might have been important sources of animal fodder for pastoral animals living in or around settlements.

\section{DISCUSSION}

A number of issues have been raised in this paper that I will now discuss in more detail. These include the circumstances and early dates for animal husbandry in the Yangshao Period, along with the cultural and environmental circumstances for the adoption of large-scale pastoralism in the late Neolithic period in the Ordos Region. The increasingly smaller proportions of wild fauna present at many 
late Neolithic to early Bronze Age sites from the Ordos Region (ca. 2500 to $1800 \mathrm{BCE}$ ) shed light on the changes in agro-pastoralism. The diversification of agricultural production and the use of both wild and domesticated animals likely accompanied changing logistics, understandings, and cultural valuations that can be linked to emerging social differences during this time period. While summarizing the evidence presented above, I will also discuss some of the implications of these issues.

The intensive exploitation of these herd animals during the late Neolithic may have been related to an adaptation to the environment. Expansions and contractions in animal husbandry may co-vary with environmental fluctuations, as individuals must attempt to balance food production strategies with the shifting availability of wild resources (Marston, 2011). As a result of emerging paleoclimatic research, some generalizations can be made about the climatic and vegetation history of this period. Proxy-based climate reconstructions based upon pollen profiles from Daihai Lake, southwestern Inner Mongolia and paleosol layers from the $\mathrm{Mu}$ Us Desert in northern Shaanxi province (Miao et al., 2016; Xiao, J. et al., 2004) demonstrate that the climate was warm and dry during the early Holocene (ca. 11.5-8.1 cal ka BP), warm and wet during the middle Holocene (ca. 8.1-3.3 cal ka BP), and cooler and drier in the late Holocene (ca. 3.3-0 cal ka BP). Pollen from Daihai Lake demonstrates that the period between ca. 7900 and 4450 cal yr BP exhibits large-scale covers of mixed coniferous and broadleaved forests, marking a warm and humid climate. During this time, the proportion of steppe vegetation such as Artemisia and arid/halophilic Chenopodiaceae expanded and replaced forest taxa.

The increased importance of caprines and cattle during the late Neolithic may be related to this documented expansion of arable grassland that began at this time in the Ordos Region. Herding strategies were likely adjusted so that the number of livestock increased in accordance with the availability of forage. Herd upkeep and production are dependent on the composition of the animal diet, and one of the major challenges herders regularly confront is maintaining access to grazing areas of sufficient nutritional quality for their animals (Makarewicz, 2014). Historically, Chinese pastoralist populations have moved to obtain forage and water for their herds and to take advantage of differences in local topography, rainfall patterns, and vegetation (Cincotta, RP. et al. 1991; Goldstein, 2012; Lattimore, 1962). However, the role of seasonal transhumance in animal husbandry practices in the late Neolithic in the Ordos Region is less clear. Herd animals were likely seasonally moving across the landscape in order to find distinctly suitable regions with rich plant fodder and water sources (Spengler et al., 2013). This hypothesis needs to be tested with more data in the future.

The cultural and ecological reasons for the development of large-scale agro-pastoralism are still unclear, but the following scenarios have been presented for other parts of the world. The over-exploitation of wild resources by small-scale hunter-gatherers of the Yangshao Period may have caused them to exploit a wider range of resources
(Flannery, 1969; Zeder, 2012). When Yangshao people began to hunt in larger more cohesive groups, increased hunting pressure may have led to resource scarcity. This explanation, however, relies on cultural determinism and a strictly evolutionary framework leaving little room for agency for individuals in the past. Another possible cultural reason for the development of large-scale agro-pastoralism is that these animals represented a type of wealth (Brunson et al., 2015; Evans-Pritchard, 1940). Domestic animals can represent a transportable resource of wealth, in either live animals or through meat, milk, and fiber (Lemmonier, 1993; Russell, 1998).

Given current evidence, it is difficult to say whether caprine and cattle arrived as a result of population movement or possibly through the diffusion, imitation, or innovation of ideas and technology across time and space. One popular explanation for the spread of agro-pastoralism to the Ordos Region, and the Northern Zone more broadly, has been a large scale migration of individuals who arrived with a Neolithic package of wheat, sheep, and bronze into already settled farming communities (Zhao, 2009). The lack of in-depth archaeological evidence from contemporary sites in surrounding regions such as Ningxia and Qinghai to the west and the Gobi Desert to the North make it difficult to substantiate this conclusion. Additionally, the current limited evidence from Yangshao period sites in southwestern Inner Mongolia and northern Shaanxi province suggest that it is possible that caprine and cattle herding spread into southwestern Inner Mongolia and northern Shaanxi province at slow gradual rates and were rapidly adopted in northern Shaanxi province during the late Neolithic period. Finally, the presence of a shared material culture across the Ordos Region makes it easy to argue that agro-pastoralist economies spread across the Ordos Region as one or as a series of discrete migration or diffusion processes. These include the presence of similar pottery styles, agricultural stone tools, and a heavy reliance on millet cultivation (Liu et al., 2016). More research is needed before these questions can be fully answered.

\section{CONCLUSIONS}

This paper uses the data generated from zooarchaeological analysis to investigate the beginning of agro-pastoralism in the Ordos Region. Zooarchaeological assemblages from middle to late Neolithic sites dating from 3,500 to $1800 \mathrm{cal}$ $\mathrm{BCE}$ provide a broad picture showing how the transition to agro-pastoralism may have taken place in this region. It was during the late Neolithic period that patterns of animal exploitation shifted from hunting to controlled herd management and animal husbandry in the Ordos Region.

The above sketch remains speculative and begs many additional research questions. Future analysis should be directed toward exploring the relationships between social transformations documented throughout the middle to late Neolithic and more detailed assessments of consumption and production strategies. Furthermore, it will be important to investigate how local patterns of land use are differentiated spatially and temporally through excavation, survey, and specialized botanical, faunal, and geoarchaeological 
analyses. Studies on the broader cultural and ecological contexts of these issues will help to explain the spread of pastoralism in the Ordos Region of China.

\section{ACKNOWLEDGMENTS}

Financial support for this study was provided by the Confucius China Joint Ph.D Scholarship (Confucius InstituteAmerican IIE) and by the Sir Robert Ho Tung Fellowship, Stanford University. Thank you to Kristina G. Douglass, Habeom Kim, and Michael Zellmann-Rohrer for critical comments on earlier drafts of this article. Two anonymous reviewers provided their constructive and very thorough comments on previous versions of this manuscript. Any responsibility for errors or opinions remains with the author alone.

\section{REFERENCES}

Anthony, D.W. 2007. The horse, the wheel, and language. Princeton (NJ): Princeton University Press.

Arbuckle, B. 2012. Pastoralism, provisioning, and power at Bronze Age Acemhöyük, Turkey. American Anthropologist 114: 462-476.

Balasse, M. and S.H. Ambrose.2005. Distinguishing sheep and goats using dental morphology and stable carbon isotopes in C4 grassland environments. Journal of Archaeological Science 32 (5): 691-702.

Barfield, T. J. 1989. The Perilous Frontier: Nomadic Empires and China. Cambridge: Cambridge University Press.

Boessneck, J. 1969.Osteological differences between sheep (Ovis aries Linné) and goats (Capra hircus Linné). In: Brothwell, D., Higgs, E. (eds). Science in Archaeology. Praeger, New York, pp. 331-358.

Bradley, D.G., D.E. MacHugh, P. Cunningham, and R.T. Loftus. 1998. Mitochondrial diversity and the origins of African and European cattle. Proceedings of the National Academy of Sciences. 93: 5131-5135.

Bradley, D.G. and D.A. Magee, 2006. Genetics and the origins of domestic cattle. In: M. A. Zeder, D.G. Bradley, E. Emshwiller, and B.D. Smith (eds). Documenting Domestication: New Genetic and Archaeological Paradigms. University of California Press: Berkeley.

Bruford M.W., and S.J. Townsend. 2006. Mitochondrial DNA Diversity in Modern Sheep: Implications for Domestication. In Zeder M, Bradley D, Emshwiller E, Smith B (eds) Documenting Domestication: New Genetic and Archaeological Paradigms, University of California Press: Berkeley. pp. 306-316.

Brunson, K. 2015. Craft Specialization and Animal Products at the Longshan Period Sites of Taosi and Zhoujiazhuang, Shanxi Province, China. Unpublished PhD Dissertation. University of California, Los Angeles.

Brunson, K., N. He, and X. Dai. 2015. Sheep, Cattle, and Specialization: New Zooarchaeological Perspectives on the Taosi Longshan. International Journal of Osteoarchaeology. 26: 460-475.

Brunson, K., X. Zhao, He, N., X. Dai, A. Rodrigues, and D. Yang. 2016. New insights into the origins of oracle bone divination: Ancient DNA from Late Neolithic Chinese bovines. Journal of Archaeological Science 74: 35-44.
Cai, D., Lu, H., X.L. Zhang, H. Zhou, and H. Zhu. 2007. DNA analysis of archaeological sheep remains from China. Journal of Archaeological Science 34: 347-55.

Cai, D. Z. Yang, H. Yu, L. Han, X. Ren, X. Zhao, H. Zhu, and H. Zhou 2011. Early history of Chinese domestic sheep indicated by ancient DNA analysis of Bronze Age individuals. Journal of Archaeological Science 38: 896-902.

Capriles, J. and Tripcevich, N. eds. 2016. The Archaeology of Andean Pastoralism. Albuquerque: University of New Mexico Press.

Campbell, R., Z. Li, Y. He, and Y. Jing. 2014. Consumption, Exchange, and Production at the Great Settlement Shang: Bone-Working at Tiesanlu, Anyang. Antiquity 85: 12791297.

Casteel, R.W. 1972. Some biases in the recovery of archaeological faunal remains. Proceedings of the Prehistoric Society 38: $382-388$

Chang C. and H.A. Koster.1986. Beyond bones: toward an archaeology of pastoralism. In Advances in Archaeological Method and Theory, ed. MB Shiffer, 9:97-148. New York: Academic.

Chen, X.L., Guo, X.D., Hu, Y.W., Wang, W.L., and C.S. Wang. 2015. Analysis of the Diet of Inhabitants at the Muzhuzhuliang Site. Kaogu yu Wenwu. 5:112-117 (In Chinese).

Chen, H., Ma, J., Li, F., Sun, Z., Wang, H., Luo, L, and F. Li. 1998. Seasonal composition and quality of red deer Cervus elaphus diets in northeastern China. Acta Theriologica 43 (1): 77-94, 1998.

Cincotta, C., van Soest, P.J. Robertson, J.B., Goldstein M.C., Beall CM 1991. Foraging ecology of livestock on the Tibetan Changtang: a comparison of three adjacent grazing areas. Arctic Alpine Research 32 (2): 149-161.

Cribb, Roger. 1991 Nomads in Archaeology. Cambridge University Press, Cambridge.

D'Alploim Guedes, J., H. Lu, Y.,Li, R.N. Spengler, X. Wu, and M.S. Aldenderfer 2014. Moving agriculture onto the Tibetan Plateau. Archaeological and Anthropological Sciences. 6 (3): 255-269.

D'Alpoim Guedes, J. 2015. Rethinking the spread of agriculture to the Tibetan Plateau. Holocene 25 (9): 1498-510.

Daihai Region Investigation Team 2001. Excavation Report of the Shihushan site. In Tian, G. and Guo, S. (eds.), Daihai Archaeology Beijing: Science Press, pp. 18-145. (In Chinese).

Di Cosmo, N. 2002. Ancient China and its Enemies. The Rise of Nomadic Power in East Asian History. Cambridge: Cambridge University Press.

Dodson, J., E. Dodson, R. Banati, X. Li, P. Atahan, Hu, S., R.J. Middleton, X. Zhou, and S. Nan. 2014. Oldest Directly Dated Remains of Sheep in China. Nature: Scientific Reports 4: 1-4.

Evans-Pritchard, E.E..1940. The Nuer: A Description of the Modes of Livelihood and Political Institutions of a Nilotic People. Oxford: Clarendon Press.

Flad, R. 2005. Zooarchaeology at Zhongba - Evaluating Fish and Meat-Salting in the Prehistoric Three Gorges, China. Journal of Field Archaeology 30 (3): 231-253.

Flad, R., Li. S., and Yuan J. 2007. Zooarcheological evidence for animal domestication in northwest China. Developments in Quaternary Sciences, 9: 167-203. 
Flannery, K.V.1969. Origins and ecological effects of early domestication in Iran and the Near East. In: Ucko, P.J., Dimbleby, G.W. (Eds.), The Domestication and Exploitation of Plants and Animals. Duckworth: London, pp. 73-100.

Frachetti, M.D. and N. Benecke. 2009. From sheep to (some) horses: 4500 years of herd structure at the pastoralist settlement of Begash (south-eastern Kazakhstan). Antiquity 83: $1023-37$.

Frachetti, M. D. 2012. Multi-Regional Emergence of Mobile Pastoralism and Non-Uniform Institutional Complexity Across Eurasia. Current Anthropology 53: 2-38.

Fuller, D.Q., J. Van Etten, K. Manning, C. Castillo, E. KingwellBanham, A. Weisskopf, L. Qin, Y. Sato, and R.J. Hijmans. 2011. The contribution of rice agriculture and livestock pastoralism to prehistoric methane levels: An archaeological assessment. The Holocene. 21(5): 743-759.

Gao, S., Sun, Z.Y., Shao,J., Wei,X., and Zhao,Z.J. 2016. Results of Flotation Analysis at the Zhaimaoliang Site, Yulin, Shaanxi Province. Nongye Kaogu 3: 14-19. (In Chinese).

Goldstein, M. C. 2012. Change and Continuity in a nomadic pastoralism community in the Tibet Autonomous Region, 1959-2009. In: H. Keutzman (ed.). Pastoral practices in High Asia: Agency of 'development' effected by modernization, resettlement and transformation. New York: Springer Publishers.

Guan, L. Hu, Y.W., Hu, S., Sun, Z.Y., Qin Ya, and C. Wang. 2008. Stable Isotope Analysis of Zooarchaeological Remains from Wuzhuangguoliang, Jingbian, Northern Shaanxi Province Quaternary Sciences 29, 6: 1160-1165 (In Chinese).

Guo, Q., Sun Z, and S. Jing. 2016. Construction techniques of the East Gate in the Outer wall of Shimao and early walledtowns in China. Kaogu yu Wenwu 4: 88-102 (In Chinese).

Han, J. 2003. China Northern Zone Region Neolithic Period Culture Research. Beijing: Beijing: Science Press. (In Chinese).

Hammer E. 2014. Local landscape organization of mobile pastoralists in southeastern Turkey. Journal of Anthropological Archaeology. 35:269-88.

Hockett, B.S.and J.A. Haws, 2002. Taphonomic and methodological perspectives of leporid hunting during the Upper Paleolithic of the western Mediterranean Basin. Journal of Archaeological Method and Theory 9 (3): 269-302.

Holguín L.and R., T. Sternberg. in press.A GIS based approach to Holocene hydrology and social connectivity in the Gobi Desert, Mongolia. Archaeological Research in Asia.

Honeychurch, W. and C. Makarewicz. 2016. The Archaeology of Pastoral Nomadism. Annual Review of Anthropology. 45:341-59.

Hu S. and Z.Y.Sun 2005. The Faunal Remains of the Wuzhangguoliang Site and Its Palaeoenvironment Analysis. Kaogu yu Wenwu, 6: 72-84. (In Chinese).

Hu S., Sun Z.Y., Yang L., Kang N.W., Yang M.M., and X. Li 2013. Research on Faunal Remains from the Yangjiesha Site in Hengshan County, Shaanxi Province. Acta Anthropologica Sinica, 32(1): 77-92. (In Chinese).

Hu S., Y. L.P., Kang N.K. Yang M. M., and X. Li. 2012. Faunal Analysis of the Shaanxi Hengshan Dagujie Site. Kaogu yu Wenwu, 4: 106-114. (In Chinese).
Hu S., Yang, M.M., Sun Z. Y., and J. Shao. 2016. 2012-2013 Shaanxi Shenmu Shimao Site Excvated Animal Bone Research. Kaogu yu Wenwu, 4: 109-122. (In Chinese).

$\mathrm{Hu}$ S., and Yuan M. 2008. Zooarchaeological Research at the Huoshiliang Site. Acta Anthropologica Sinica, 27(3): 232248. (In Chinese).

Huang, Y. 1996. Zooarchaeological Identification and Research at Zhukaigou, Inner Mongolia. Kaogu Xuebao, 4: 515-536. (In Chinese).

Huang Y. 2001. Identification and study of faunal remains from the Shihushan I site]. In: Tian, G. and Guo, S. (eds.) Daihai Archaeology. Beijing: Science Press, pp. 489-513 (in Chinese).

Indrisano, G. G. 2006. Subsistence, Environmental Fluctuation and Social Change: A Case Study in South Central Inner Mongolia. Ph.D. dissertation, University of Pittsburgh.

Ingold, T. 1980. Hunters, Pastoralists and Ranchers: Reindeer Economies and their Transformations. Cambridge University Press, Cambridge, UK.

Inner Mongolian Provincial Institute of Archaeology. 2000. Zhukaigou: Bronze Age Early Site, Excavation Report. Beijing: Wenwu Chubanshe. (In Chinese).

Inner Mongolia Institute of Cultural Relics. 2003. Miaozigou and Dabagou-Report on the excavations of two Neolithic sites. Beijing: Zhongguo dabaikequanshu chubanshe. (In Chinese).

Inner Mongolia Institute of Archaeology and Japanese Capital Archaeological Research Institute. 2001a. Daihai Archaeology (2): Sino-Japanese Daihai region archaeological research report. Beijing: Science Press.

Janz, L. 2016. Fragmented Landscapes and Economies of Abundance: The Broad-Specrum Revolution in Arid East Asia. Current Anthropology. 57 (5): 537-562.

Janz, L., R.G. Elston, and G. S. Burr. 2009.Dating Northeast Asian surface assemblages with ostrich eggshell: implications for palaeoecology and extirpation. Journal of Archaeological Science 36:1982-1989.

Kang, N.W. 2013. Yulin City Yangshao Period Remains. Kaogu yu Wenwu, 4: 45-53. (In Chinese).

Kerley, G.I.H. 1990. Browsing by Lepus capensis in the Karoo. South African Journal of Zoology. 25 (3): 199-200.

Khazanov, A. 1984. Nomads and the Outside World. Cambridge: Cambridge University Press.

Krader, L. 1959. The ecology of nomadic pastoralism. International Social Science Journal, 11: 499-510.

Lane, K. 2006. Through the looking glass: re-assessing the role of agro-pastoralism in the north-central Andean highlands. World Archaeology 38:493-510.

Lattimore, O. 1962. Inner Asian Frontiers of China. Beacon Press, Boston.

Lemonnier, P. 1993. Pigs as ordinary wealth: technical logic, exchange, and leadership in New Guinea. In P. Lemonnier (ed.), Technological Choice: Transformations in Material Culture since the Mesolithic. London: Routledge. pp. 12656.

Linduff, K. M. 1997. An Archaeological Overview. In: E. C. Bunker (Ed.), Ancient Bronzes of the Eastern Eurasian Steppes. New York: Arthur M. Sackler Foundation. pp. 18-98.

Liu, L. and X. Chen. 2012. The Archaeology of China: From the Late Paleolithic to the Early Bronze Age. Cambridge: Cambridge University Press. 
Liu, L., L. Kealhofer, X. Chen, and Ping, J. 2014. A broad-spectrum subsistence economy in Neolithic Inner Mongolia, China: Evidence from grinding stones. The Holocene. 24(6): 726-742.

Liu, L., X. Chen, and Ping, J. 2016. Understanding Household Subsistence Activities in Neolithic Inner Mongolia, China: Functional Analyses of Stone Tools. Journal of Anthropological Research. 72(2): 226-247.

Luo, Y.B. 2012. Chinese Ancient Pig Domestication: Animal Husbandry and Ritual Use. Beijing: Scientific Press. (In Chinese).

Lu, P. 2010. Discussion of the origins of Chinese domestic cattle. Dongwu Kaogu, (1): 152-176. Beijing: Wenwu Chubanshe. (In Chinese).

Makarewicz, C. 2014. Winter pasturing practices and variable fodder provisioning detected in nitrogen $(\mathrm{d} 15 \mathrm{~N})$ and carbon (d13C) isotopes in sheep dentinal collagen. Journal of Archaeological Science. 41:502-510.

Marston, J. M. 2011. Archaeological markers of agricultural risk management. Journal of Anthropological Archaeology 30:190-205.

McClure S. 2015. The pastoral effect: niche construction, domestic animals, and the spread of farming in Europe. Current Anthropology 56 (6): 901-10.

Miao, Y., H. Jin, and J. Cui 2016. Human activity accelerating rapid desertification of the Sandy Lands, North China. Scientific Reports, 6, 23003: 1-6.

Miller, N.F. Zeder, M.A., and S.R.Arter. 2009. From food and fuel to farms and flocks: The integration of plant and animal remains in the study of the agropastoral economy at Gordion, Turkey. Current Anthropology. 50 (6): 915-924.

Miller, N.F. and J.M. Marston. 2012. Archaeological fuel remains as indicators of ancient West Asian agropastoral and landuse systems. Journal of Arid Environments 86: 97-103.

Owlett, T.E., Hu S., Sun Z.Y., and J. Shao,in press. Food between the Country and the City: The Politics of Food Production at Shimao and Zhaimaoliang. Archaeological Research in Asia.

Orton, D. 2010. Both subject and object: herding, inalienability and sentient property in prehistory. World Archaeology 42(2): 188-200.

Payne, S. 1975. Partial recovery and sample bias. In: A. T. Clason (Ed.), Archaeozoological studies. Amsterdam: North-Holland Publishing Company; Pp. 7-17.

Quitmyer I. 2004. What kind of data are in the back dirt? An experiment on the influence of screen size on optimal data recovery. Archaeofauna 13: 109-129.

Rhode, D., D.B. Madsen, P.J. Brantingham and T. Dargye. 2007. Yaks, Yak Dung and Prehistoric Human Occupation of the Tibetan Plateau. In: D.B. Madsen, Chen, F. and G. Xing (eds.). Late Quaternary Climate Change and Human Adaptation in Arid China Elsevier, Amsterdam. Pp. 205-226

Russell, N. 1998. Cattle as wealth in Neolithic Europe: Where's the beef? In: D.W. Bailey (ed.) The Archaeology of Value: Essays on Prestige and the Processes of Valuation. British Archaeological Reports. International Series. Oxford: British Archaeological Reports, pp. 42-54

Salzman P.C. 1971. Movement and resource extraction among pastoral nomads: the case of the Shah Nawazi Baluch. Anthropology Quarterly 44:185-197.
Shaanxi Provincial Institute of Archaeology, Yulin Archaeology and Cultural Relics Team, Shenmu Cultural Relics Bureau. 2016. Preliminary report on the excavation of Hangjiagedan locus at the Shimao Site in Shenmu, Shaanxi. Kaogu yu Wenwu 4: 14-25 (In Chinese).

Shannxi Provincial Institute of Archaeology, Yulin Archaeology and Cultural Relics Team, Shenmu Cultural Relics Bureau. 2013. The Shimao Site in Shenmu county, Shaanxi], Kaogu 7:15-24 (In Chinese).

Shelach, G. 2005. Early pastoral societies of northeast China: local change and interregional interaction during c. 1100-600 BC. In: R. Amitai, M.Biran (eds.) Mongols, Turks, and Others: Eurasian Nomads and the Outside World, Leiden, Neth: E.J. Brill, pp. 15-58..

Shelach, G. 2009b. Violence on the Frontiers? Sources of Power and Sociopolitical Change at the Easternmost Parts of the Eurasian Steppe during the Late Second and Early First Millennium BCE. In: K. Linduff, B.K. Hanks (eds.), Social Complexity in Prehistoric Eurasia: Monuments, Metals, and Mobility Cambridge: Cambridge University Press. pp. 241-271.

Speth, J. and Spielmann, K. 1983. Energy source, protein metabolism, and hunter-gatherer subsistence strategies. Journal of Anthropological Archaeology 2 (1): 1-31.

Spengler, R. N., M.D. Frachetti, and G.J. Fritz. 2013a. Ecotopes and herd foraging practices in the Steppe/Mountain ecozone of central Asia During the Bronze and Iron ages. Journal of Ethnobiology 33(1): 125-147.

Spengler, R.N., C. Chang, and P.A. Tourtellotte. 2013b. Agricultural production in the Central Asian mountains: Tuzusai, Kazakhstan (410-150 B.C.). Journal of Field Archaeology 38 (1): 68-85.

Stiner, M.C., Munro, N.D., and Surovell, T.A., 2000. The tortoise and the hare: small game use, the Broad Spectrum Revolution, and Paleolithic demography. Current Anthropology 41: 39-73.

Sun, Z.Y. 2005. Discussion on the Xinhua Culture. Kaogu yu Wenwu, 3: 40-59. (In Chinese).

Sun, Z.Y. 2016. Investigation of the process of social complexity in Northern China during the third millennium B.C. Kaogu yu Wenwu 4: 70-80 (In Chinese).

Tian, G. and Guo, S. 2004.On prehistoric settlement patterns in the circum - Daihai region. In: Tian, G. and Guo, S. (eds.) Collected Papers on Archaeology of North Region. Beijing: Science Press, pp. 287-327 (in Chinese).

Wagner, M., X. Wu, P. Tarasov, A. Aisha, C. Bronk Ramsay, M. Schmidt-Schultz, and J. Gresky. 2011. Radiocarbon-dated archaeological record of early first millennium B.C. mounted pastoralists in the Kulun Mountains, China. Proceedings of the National Academy of Sciences, 108(38): 15733-15738.

Wang, M.K. 1994. The Origins of Specialized Pastoralism in the Ordos and Neighboring Area. Bulletin of the Institute of History and Philology, 64(2): 375-434.

Wang, W.L.and Guo, X. 2016. Research on the Settlement Pattern and Society during the Longshan and Xia Periods in Northern Shaanxi Region. Kaogu yu Wenwu 4: 52-60. (In Chinese).

Wang, X. and Zhang, G. Research on the late Longshan archaeological remains at the Bicun site in Xing County, Shanxi. Kaogu yu Wenwu 4: 80-88 (In Chinese). 
Wang, Y. 2015. The Origins of Sheep and Goat Domestication in Western China. Unpublished PhD Dissertation. Cambridge University, U.K.

$\mathrm{Wu}, \mathrm{B}$. and Ci L.2002. Landscape change and desertification development in the Mu Us Sandland, Northern China. Journal of Arid Environments, 50: 429-444.

Xia, X. Sun, Z.Y., Yang, L.P., Kang, N.W., Chen, X.L., Wang, C., and Wu, Y. 2015. Phytolith analysis from the archaeological site of Wangyangpan, Yulin, North Shaanxi. Acta Anthropologica Sinica, 34 (4): 1-1 (In Chinese).

Xiao, J., Xu, Q., Nakamura, T., Yang, X., Liang, W., and Inouchi, Y. 2004. Holocene vegetation variation in the Daihai Lake region of north-central China: a direct indication of the Asian monsoon climatic history. Quaternary Science Reviews, 23(14-15): 1669-1679.

Xu, Q., Yuecong, L., Xiaolan, Y., Jule, X., Wendong, L., and Yanjia, P. 2005. Source and distribution of pollen in the surface sediment of Daihai Lake, Inner Mongolia. Quaternary International, 136(1): 33-45.

Yi, M-j., L. Barton, C. Morgan, D. Liu, F. Chen, Y. Zhang, S. Pei, Y. Guan, H. Wang, X. Gao, and R.L. Bettinger. 2013.Microblade technology and the rise of serial specialists in north-central China. Journal of Anthropological Archaeology (32): 212-223.

Yuan J. 2010. Zooarchaeological research concerning animal domestication in ancient China. Disiji Yanjiu 30: 298-306. (In Chinese).

Yu, C., L. Peng, and C. Zhao. 2011. Identification and research on animal bones from Xishan, Li County, Gansu Province. Nanfang Wenwu (3):73-79 (In Chinese).

Zhao, Z. 2009. Eastward Spread of Wheat into China: New Data and New Issues. Chinese Archaeology 9: 1-9.

Zeder, M. and Pilaar, S.E. 2009. Assessing the reliability of criteria used to identify mandibles and mandibular teeth in sheep, Ovis, and goats, Capra. Journal of Archaeological Science 37: 225-242.

Zeder, M. 2011. The origins of agriculture in the Near East. Current Anthropology 54(S4): S221-S235.

Zeder, M. 2012. The Broad Spectrum Revolution at 40: Resource diversity, intensification, and an alternative to optimal foraging explanations. Journal of Anthropological Archaeology 31(3): 241-264.

Zhao, C., Hu S., Sun Z.Y., Jing, S., and Yang, M.M. 2016. Strontium Isotopic Analysis of Teeth Dental Tissues from the Houyangwan Locus at the Shimao Site in Shenmu, Shaanxi. Kaogu yu Wenwu 4: 128-134. (In Chinese) 